TOLGA TEMUCIN, Ph.D. ${ }^{1}$

(Corresponding author)

E-mail: tolga.temucin@gmail.com

GULFEM TUZKAYA, Ph.D. ${ }^{1}$

E-mail: gulfem.tuzkaya@marmara.edu.tr

OZALP VAYVAY, Ph.D. ${ }^{1}$

E-mail: ozalp@marmara.edu.tr

${ }^{1}$ Marmara University

Department of Industrial Engineering

Goztepe Campus, 34722 Kadikoy - Istanbul, Turkey
Transport Technology

Review

Submitted: 22 Jan. 2021

Accepted: 31 May 2021

DOI: $10.7307 /$ ptt.v33i4.3793

\title{
AIRCRAFT MAINTENANCE ROUTING PROBLEM - A LITERATURE SURVEY
}

\begin{abstract}
The airline industry has shown significant growth in the last decade according to some indicators such as annual average growth in global air traffic passenger demand and growth rate in the global air transport fleet. This inevitable progress makes the airline industry challenging and forces airline companies to produce a range of solutions that increase consumer loyalty to the brand. These solutions to reduce the high costs encountered in airline operations, prevent delays in planned departure times, improve service quality, or reduce environmental impacts can be diversified according to the need. Although one can refer to past surveys, it is not sufficient to cover the rich literature of airline scheduling, especially for the last decade. This study aims to fill this gap by reviewing the airline operations related papers published between 2009 and 2019, and focus on the ones especially in the aircraft maintenance routing area which seems a promising branch.
\end{abstract}

\section{KEYWORDS}

airline operations; airline scheduling; aircraft maintenance routing.

\section{INTRODUCTION}

The airline industry impacts the welfare level of countries with its numerous economic and social benefits. According to the Air Transport Action Group [1], this industry creates 65.5 million jobs worldwide and contributes approximately 2.7 trillion dollars a year to the world Gross Domestic Product. Additionally, developing social networks, creating new trade links, fast and reliable access to remote parts of the world, tourism, and environmental sustainability are some of the other bene- fits of this industry in which inevitable progress continues day by day. One of the indicators of this progress is that annual average growth in global air traffic passenger demand was 5.84\% between 2006 and 2019 [2]. According to the second indicator, the growth rate of the global air transport fleet in the Middle East will be $5.6 \%$ by 2023 [3].

This progress in the airline industry forces companies to take a range of precautions to increase their market share in this sector. These precautions such as reducing costs, preventing delays, improving service quality, decreasing environmental impacts, etc. vary depending on airline operation type. Airline operations are classified as Flight Scheduling Problems (FSP), Fleet Assignment Problems (FAP), Maintenance-Repair-Overhaul (MRO) activities, and Crew Scheduling Problems (CSP). To expand the scope of this study, it would be useful to include schedule recovery operations, and Air Traffic Control Problems (ATCP) in the current classification. Although such operations have been studied for several years, the challenge still exists because of the increasing size of the industry and the high complexity of airline networks. In this context, the fact that the abovementioned reviews do not contain the rich literature of the last decade constitutes the basis of this study. For this reason, in this study, firstly the studies published on airline operations between the years 2009 and 2019 were examined to get an idea at a general level, and then the studies related to the Aircraft Maintenance Routing Problem (AMRP) were investigated in more depth due to the following reasons. 
- Recently, aviation and airline maintenance providers are some of the most significant worldwide industries.

- MRO costs can vary between 10 and 45\% depending on the aircraft type [4] and its age. This means that a lack of coordination and planning in MRO activities can cause monetary losses and also adversely affect the airlines brand.

Factors such as loss of life, reputation cost, monetary loss, etc. have caused the aviation industry to focus on maintenance operations lately. Otherwise, the increasing number of planes and passenger demand would probably have cause for greater catastrophes. Over the last 10 years, the airline industry has improved its overall safety performance by 54\%. The accident rate in 2016 dropped to 1.61 , compared to 3.53 accidents per million flights in 2007 [5]. Because of this situation, which shows the importance of MRO activities, the focus of this review has been determined to be the studies on Aircraft Maintenance Routing (AMR) operations. Based on this information, this paper is organised as follows: Section 2 outlines the methodology applied. Section 3 is devoted to some preliminary findings, while section 4 provides a detailed analysis of AMR studies. A discussion part is presented in section 5 and finally, conclusions are drawn in section 6 .

\section{SURVEY METHODOLOGY}

Before searching the relevant studies in the literature, a schema was created. During the review, ScienceDirect, Springer, Institute of Electrical and Electronics Engineers (IEEE), Emerald, and Google Scholar databases were investigated and in the end, 117 papers which were published in international journals or conference proceedings during the 2009-2019 period were identified. Finally, these papers were analysed, classified, and recorded under the designed schema.

\section{PRELIMINARY FINDINGS}

The main purpose of this article is to conduct a literature review covering the last 10 years for a single type of airway operation. This section is therefore devoted to one thing: To determine the type of airline operation which is focused more in order to justify the next section's subject. Therefore, in this section, we tried to determine the areas on which the 117 studies are concentrated the most.

\subsection{Focused area(s)}

In the previous sections, it was stated that the airline industry is a sector that is constantly developing due to its possible economic and social effects. This situation triggers the efforts of companies operating in this field to increase their market shares and therefore leads to the emergence of new solutions that increase customer satisfaction, reduce costs, and prevent delays as much as possible. These developments are a product of academic studies in different areas of the airline industry. Table 1 displays the aforementioned studies conducted between 2009 and 2019, and the types of operations focused on in these studies.

The first judgment that can be drawn from Table 1 is whether academics prefer to work in one field or more than one field at the same time. Airlines may choose to examine the selected problem areas step by step. Although this method simplifies the overall process, it causes a small reduction in costs. Most problem types in airline scheduling are known to belong to a class of problems called "Non-deterministic Polynomial-Time (NP)-Hard". In such problems, integrating a new problem into the calculation process causes the solution cost to increase exponentially and reduces the possibility of finding a fast method that can solve the final problem. In addition, even a small improvement in any of the airline scheduling problems will result in big gains. American Airlines reported a 5\% revenue increase (about $\$ 1.4$ billion over three years) in 1992 due to the introduction of a new yield management system [123]. In 1994, Delta Air Lines estimated that the use of a newly developed fleet assignment system would yield savings of up to $\$ 300$ million over the following three years [124]. Therefore, it seems reasonable to approach each of the existing problems step by step. On the other hand, a major drawback of this sequential approach is that it ignores most of the interdependencies between the selected problems. In particular, it fails to build robust solutions that are resilient to unpredictable disruptions (like adverse weather, aircraft breakdowns, etc.) that translate into delayed and cancelled flights [15]. Hence, examining selected problems at the same time will make the process more complicated but result in further cost reduction. This is a trade-off that needs to be settled. This question has been answered in favour of studies conducted in a single 
Table 1 - Focused areas in each study

\begin{tabular}{|c|c|c|c|c|c|c|c|c|c|c|c|}
\hline \multirow[b]{2}{*}{ Authors } & \multirow[b]{2}{*}{ क्ष } & \multirow[b]{2}{*}{$\sum_{1}^{2}$} & \multirow[b]{2}{*}{ चे } & \multirow[b]{2}{*}{$\hat{\approx}$} & \multirow[b]{2}{*}{ 宅 } & \multicolumn{6}{|c|}{ MRO Subjects } \\
\hline & & & & & & $\sum_{\&}$ & $\stackrel{\mathscr{\Omega}}{\Xi}$ & $\bar{n}$ & $\xi$ & 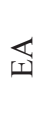 & $\frac{n}{\tilde{D}}$ \\
\hline Chen et al. [6], Zhou and Zhang [7], Colbacchini et al. [8] & & & & & & & $\sqrt{ }$ & & & & \\
\hline $\begin{array}{l}\text { Diaz-Ramirez et al. [9], Weide et al. [10], Dunbar et al. [11], Mohamed et al. } \\
\text { [12], Parmentier and Meunier [13], Mohamed et al. [14], Ahmed et al. [15] }\end{array}$ & & & $\sqrt{ }$ & & & $\sqrt{ }$ & & & & & \\
\hline $\begin{array}{l}\text { Lacasse-Guay et al. [16], Papakostas et al. [17], Yang and Yang [18], Maher } \\
\text { et al. [19], Liang et al. [20], Başdere and Bilge [21], Irvine et al. [22], } \\
\text { Gopalan [23], Al-Thani et al. [24], Safaei and Jardine [25], Qin et al. [26], } \\
\text { Sarhani et al. [27], Eltoukhy et al. [28], Orhan et al. [29], Aslamiah et al. } \\
\text { [30], Afsar et al. [31], Kim et al. [32], Bulbul and Kasimbeyl1 [33], Zhong } \\
\text { et al. [34], Afia and Sarhani [35], Zhang [36], Eltoukhy et al. [37], Cui et al. } \\
\text { [38], Eltoukhya et al. [39] }\end{array}$ & & & & & & $\sqrt{ }$ & & & & & \\
\hline $\begin{array}{l}\text { Vos et al. [40], Zhang et al. [41], Dožic et al. [42], Liu et al. [43], Hu et al. } \\
\text { [44], Jufri et al. [45], Lin and Wang [46] }\end{array}$ & & & & & $\sqrt{ }$ & & & & & & \\
\hline $\begin{array}{l}\text { Akartunalı et al. [47], Akartunalı et al. [48], Burke et al. [49], Chen et al. } \\
\text { [50], Sun [51], Jiang and Barnhart [52], Abdelghany et al. [53], Sandamali et } \\
\text { al. [54], Zhao et al. [55], Peng et al. [56], Chen et al. [57], Wang and Zhang } \\
\text { [58], Ahmadian et al. [59] }\end{array}$ & $\sqrt{ }$ & & & & & & & & & & \\
\hline $\begin{array}{l}\text { Azadeh et al. [60], Deng and Lin [61], Ionescu and Kliewer [62], Dück } \\
\text { et al. [63], Saddoune et al. [64], Suraweera et al. [65], Bayliss et al. [66], } \\
\text { Kasirzadeh et al. [67], Lijima and Nishi [68], Arayikanon and Chutima [69] }\end{array}$ & & & $\sqrt{ }$ & & & & & & & & \\
\hline $\begin{array}{l}\text { Özdemir et al. [70], Pilla et al. [71], Kang et al. [72], Yang et al. [73], Ma et } \\
\text { al. [74], Raudasoja [75], Boudia et al. [76], Liu et al. [77], Dozic et al. [78], } \\
\text { Okafor et al. [79], Anzoom and Hasin [80], Silva and Poss [81], Su et al. } \\
\text { [82], Dahel [83] }\end{array}$ & & $\sqrt{ }$ & & & & & & & & & \\
\hline Bruecker et al. [84], Qiang et al. [85], MacKenzie et al. [86], Datta et al. [87] & & & & & & & & & $\sqrt{ }$ & & \\
\hline Gürkan et al. [88] & $\sqrt{ }$ & $\sqrt{ }$ & & & & $\sqrt{ }$ & & & & & \\
\hline $\begin{array}{l}\text { Dong et al. [89], Cadarso and Marin [90], Pita et al. [91], Cadarso and Marin } \\
\text { [92], Kenan et al. [93], Mezentsev and Estraykh [94] }\end{array}$ & $\sqrt{ }$ & $\sqrt{ }$ & & & & & & & & & \\
\hline $\begin{array}{l}\text { Tsagkas et al. [95], Gerede [96], Gerede [97], Chang and Wang [98], Atak } \\
\text { and Kingma [99], Quinlan et al. [100], Passenier et al. [101] }\end{array}$ & & & & & & & & $\sqrt{ }$ & & & \\
\hline Murça and Müller [102], Samà et al. [103], Samà et al. [104] & & & & & $\sqrt{ }$ & & & & & & \\
\hline $\begin{array}{l}\text { Shanmugam and Robert [105], Yadav [106], Kasava et al. [107], Mofokeng } \\
\text { and Marnewick [108] }\end{array}$ & & & & & & & & & & & $\sqrt{ }$ \\
\hline Noweir and Zytoon [109], Irwin and Streilein [110] & & & & & & & & & & $\sqrt{ }$ & \\
\hline Babic et al. [111], Sandamali et al. [112], Lindner et al. [113] & $\sqrt{ }$ & & & & & & $\sqrt{ }$ & & & & \\
\hline Jamili [114], Liu et al. [115] & & $\sqrt{ }$ & & & & & $\sqrt{ }$ & & & & \\
\hline Özener et al. [116], Komijan and Tavakkoli-Moghaddam [117] & & $\sqrt{ }$ & $\sqrt{ }$ & & & & & & & & \\
\hline $\begin{array}{l}\text { Abdelrahman [118], Chan and Eltoukhy [119], Eltoukhya et al. [120], } \\
\text { Eltoukhya et al. [121] }\end{array}$ & & & & & & & $\sqrt{ }$ & & & $\sqrt{ }$ & \\
\hline Safaei [122] & & & & & & & $\sqrt{ }$ & & & & $\sqrt{ }$ \\
\hline Total & 23 & 25 & 19 & 7 & 3 & 42 & 3 & 7 & 8 & 2 & 5 \\
\hline
\end{tabular}

Note: EA: Ergonomic Assessment; MP: Maintenance Personnel; MTIS: Maintenance Tracking Info Systems;

SI: Safety Issues; SRP: Schedule Recovery Problem

field with $78 \%$ in the last 10 years. The ratio for the studies having multi-domain corresponds to only $22 \%$ of all studies.

The second conclusion that can be drawn from Table 1 is the areas that the academics prefer to study the most. This is represented in Figure 1. Figure 1 expresses that the number of articles on MRO is close to half of the current studies which shows the importance given to maintenance in airline scheduling. Besides, AMRP is the most frequently studied subject in the MRO related articles. On the other hand, when the four main operations were 


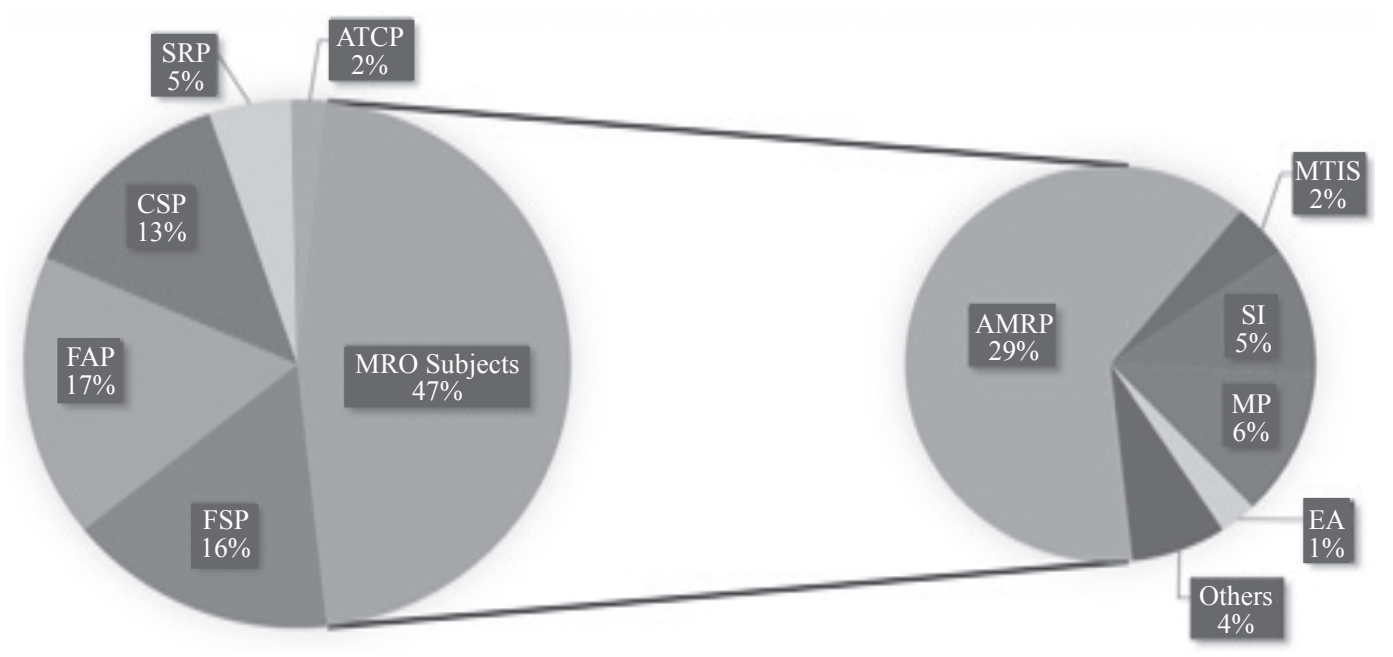

Figure 1 - Sub-problem distribution

compared, it was observed that the percentages of articles on FSP, FAP, and CSP were close to each other, while the percentage of articles related to AMRP was approximately twice of these.

\subsection{Distribution of studies by publication year}

The number of studies on airline scheduling tends to increase annually. The number of studies in the 2015-2019 period is approximately twice the studies published in the 2009-2014 period. In addition, when compared to other problems, AMRP, which is studied almost every year, is the most popular problem type in the 2009-2019 period.

\section{AIRCRAFT MAINTENANCE ROUTING PROBLEM}

The AMR process includes the determination of the sequence of flight legs to be flown by each individual aircraft so as to cover each flight exactly once while satisfying maintenance requirements $[16,24]$. The general characteristics of the AMRP studies and a brief summary of the goals used thereof are presented in this section. Table 2 summarises those features which will be examined in detail below.

\subsection{Maintenance consideration}

Although there is no consistency in the used literature, Bergh et al. [125] provided a framework by using the most common maintenance definitions. Within this framework, the columns refer to the intensity of the workload, starting from short-term (frequent and light) to long-term (rare and heavy) maintenance. On the other hand, the rows refer to the uncertainty level showing whether the maintenance is planned or not.

In practice, each aircraft has many maintenance tasks, with over 50 different checks, which must be done on a regular basis during the life cycle [25]. These checks vary according to their scope, duration, and frequency. Additionally, the periodicity of these checks depends on the aircraft type and internal rules of the airlines [24]. The most common of these checks is A-check which must be performed every 65-125 flight hours. Other sources indicate that A-check is supposed to be issued once every $3-5$ days $[16,29]$, or every week. An A-check which involves visual inspection of major systems lasts 8 hours at most. This duration is sufficient for aircraft to be maintained overnight. Papakostas et al. [17] considered the aforementioned short-term line maintenance activities in their approach. According to their approach, at any point of time when a set of maintenance tasks that can be deferred exist, a decision should be made. These decisions constitute a set of alternatives which are defined as the possible allocation of pending maintenance tasks to suitable resources either at the current or at successive airports. Maher et al. [19] presented an approach to find a single day aircraft routing plan. This solution is further protected from disruptions by applying the recoverable robustness framework whose primary concern is to achieve A-check maintenance feasibility while simultaneously improving the recoverability of the aircraft routing plan. Başdere and Bilge [21] developed a fast responsive methodology with the objective of minimizing the unused legal flying times within the fleet. In their study, a 
Temucin T, Tuzkaya G, Vayvay O. Aircraft Maintenance Routing Problem - A Literature Survey

\begin{tabular}{|c|c|c|c|c|c|c|c|c|c|c|c|c|c|c|c|c|c|c|c|c|c|c|c|c|c|c|c|c|c|c|c|}
\hline 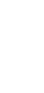 & 当 & & & & $>$ & & & & & & & & & & & & & & & & & & & $>$ & & & & & & & $\sim$ \\
\hline ర్ & 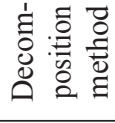 & $>$ & & & & $>$ & & $>$ & $>$ & & & & & & & & & & & & & & & & & & & & & & $n$ \\
\hline 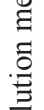 & 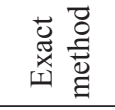 & & & $>$ & & 7 & & & & & & $>$ & & & & $>$ & & 7 & & & & & & $>1$ & & & & & & & 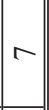 \\
\hline $\bar{O}$ & 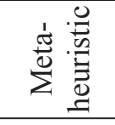 & & & & & & $>$ & & & & & $>$ & $>$ & & & & & & $>$ & & & & $>$ & & $>$ & 7 & & $>$ & $>$ & & $a$ \\
\hline 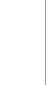 & $\stackrel{\dot{d}}{\stackrel{1}{I}} \cdot \stackrel{0}{\stackrel{0}{\Xi}}$ & $>$ & $>$ & $>$ & & $>$ & & & $>$ & $>$ & $>$ & $>$ & & & $>$ & & & & & $>$ & & $>$ & $>$ & & & & & & & $>$ & 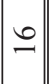 \\
\hline$\nabla$ & $\begin{array}{l}\vec{E} \\
\stackrel{0000}{Z}\end{array}$ & $>$ & $>$ & & & & & $>$ & & & & & & & & & & & & & & & & $>1$ & & & & & $>$ & $>$ & $\simeq$ \\
\hline 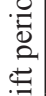 & 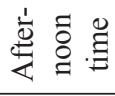 & & & & & & & & & & & & & & & & & & & & & & & $>$ & & & & & $>$ & & $\sim v$ \\
\hline $\bar{\sim}$ & 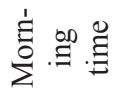 & & & & & & & & & & & & & & & & & & & & & & & $>$ & & & & & $>$ & $>$ & $m$ \\
\hline 코․ & 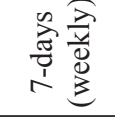 & $>$ & & & & & & & & $>$ & & $>$ & $>$ & & 7 & $>$ & & & & & & & $>$ & & & & $>$ & & & & $a$ \\
\hline $\begin{array}{l}\tilde{\Xi} \\
\stackrel{\Xi}{\Xi} \\
. \Xi\end{array}$ & 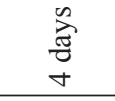 & & & & & & & & & & & & & & & & & & & $>$ & & & & & & $>$ & & & $>$ & $>$ & $\nabla$ \\
\hline- & 胥祘 & & & $>$ & & & & $>$ & & & & & & $>$ & & & & $>$ & $>$ & & $>$ & $>$ & & $>1$ & $>$ & & & $>$ & & & 으 \\
\hline 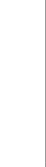 & 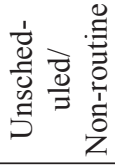 & & & & & & & & & & & & & & & & & & $>$ & & & & & & $>$ & & & & & & $\sim$ \\
\hline . & 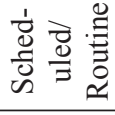 & & & & & & & & & & & & & & & & & & & & & & & $>$ & & & & & & & -1 \\
\hline $\begin{array}{c}\overline{0} \\
\frac{0}{0} \\
\overline{0} \\
0\end{array}$ & 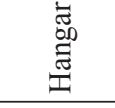 & & & & & & & & & & & & & & & & $>$ & & & & & & & & & & & & & & -1 \\
\hline 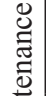 & 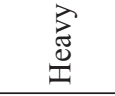 & & & & & & & & & & & & & & & & $>$ & & & & & & & & & & & & & & -1 \\
\hline 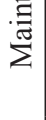 & $\begin{array}{l}\frac{y}{0} \\
y \\
\frac{U}{0} \\
\dot{1} \\
\end{array}$ & & & & & & & $>$ & & $>$ & & & & & & & & & $>$ & $>$ & & & & & & $>$ & & $>$ & $>$ & $>$ & $a$ \\
\hline & $\stackrel{\varrho}{\Xi}$ & & & & $>$ & & & & & & & & & & & $>$ & & & & & & & & & & & & & & & $\sim v$ \\
\hline & 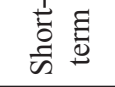 & & & & $>$ & & & & & $>$ & & & & & & & & & & & $>$ & & & & & & & & & & $m$ \\
\hline & 号 & 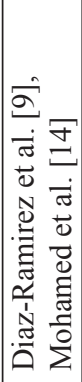 & 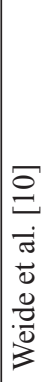 & 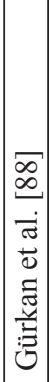 & 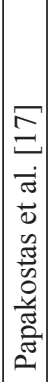 & 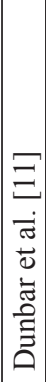 & 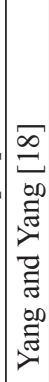 & 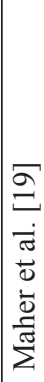 & 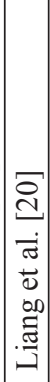 & 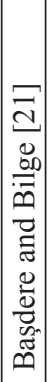 & 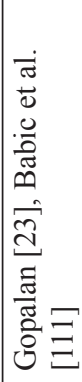 & 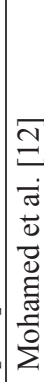 & 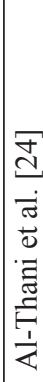 & 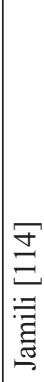 & 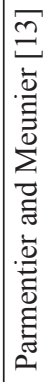 & 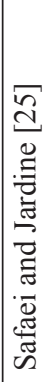 & 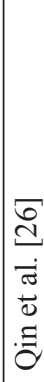 & 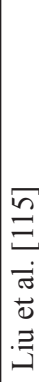 & 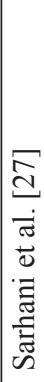 & 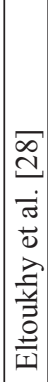 & 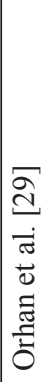 & 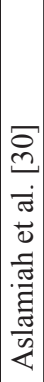 & 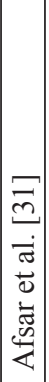 & 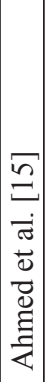 & 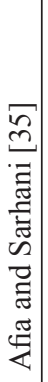 & 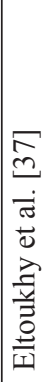 & 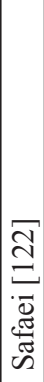 & $\begin{array}{l}\sigma \\
m \\
\dot{m} \\
\dot{\sigma} \\
\tilde{0} \\
\dot{\Xi} \\
\tilde{J}\end{array}$ & 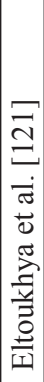 & 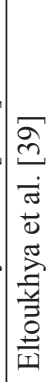 & 全 \\
\hline
\end{tabular}


branch-and-bound algorithm and a heuristic approach are used to solve the model they formulated. Furthermore, they presented a procedure to revise the existing routes while considering the maintenance decisions which are already made. Al-Thani et al. [24] used a graph reduction procedure to improve the solvability of the Operational Aircraft Maintenance Routing Problem (OAMRP) model. Eltoukhy et al. [28] and Orhan et al. [29] studied the OAMRP taking into account some operational constraints related to the daily maintenance process.

Other maintenance types such as B-check, C-check, and D-check take longer and are repeated at longer intervals. B-check is repeated every $300-600$ hours of flying or once in a month and lasts around 1-3 days. This involves a more extensive visual inspection and also lubrication of all moving parts. C-check and D-check are repeated once every 1-4 years. These checks can only be completed in a month in specialised hangars. Although past AMRP studies have included many types of maintenance, these studies mostly considered the A-type maintenance instead of the long-term checks. This is because longer checks directly affect fleet capacity which is why such checks should be considered during FAP [21]. One of these rare studies is the Qin et al. [26] study, where hangar maintenance scheduling and parking layout planning problems were tackled together to minimise total maintenance delay.

The above maintenance is routine maintenance planned according to variables such as the number of landings or flight hours after the last inspection. On the other hand, checks with a high level of uncertainty are called unscheduled or non-routine maintenance. The unscheduled aircraft maintenance occurs anytime a component/unit has malfunctioned or is suspected of malfunctioning, and by definition, this maintenance is unforeseen. That is why it can be classified as either a corrective or predictive measure. Sarhani et al. [27] modelled the daily AMRP problem, whose aim is to minimise the planned and unplanned maintenance costs, and developed a new particle swarm optimization algorithm integrated with a population diversity-enhancing mutation operator to use as the solution of the problem. Afia and Sarhani [35], an advanced version of Sarhani et al. [27], is another study on unplanned maintenance checks.

\subsection{Time horizon and shift period}

Three types of time horizon, namely daily, 4 days, and weekly, are considered in the past studies. Weekly time horizon is the longest planning period in the past AMRP studies. There are two conflicting ideas in the literature regarding this time horizon. From one perspective, the weekly planning period is too optimistic for frequent disruptions in the airline industry. According to this view, the impact of stochastic events (severe weather changes, equipment failures, variable maintenance times, or even new regulations, etc.) having unknown occurrence time and frequency on the planning period is vital. Long planning periods in the airline industry can cause unnecessary repetition of similar processes and increase operational costs. In addition, in this approach, aircraft whose maintenance needs are not at critical levels should also be maintained. However, maintaining these aircraft earlier than necessary is contradictory to the goal of maximizing productivity because the scarce maintenance resources needed for the critical aircraft are consumed unnecessarily. On the other hand, the solution to a problem with a longer time horizon may indeed better utilise the remaining flying hours of the aircraft by delaying the maintenance of some critical aircraft beyond the current day but still within the legal limits [30]. A time horizon that works well on one data can prevent good solutions in another. For this reason, the process of determining the time horizon, which is similar to being on a knife edge, is perhaps one of the most important factors in solving AMRP problems.

Accepting that long time horizon gives better results, Afsar et al. [31] created a flight plan that takes into account the aircraft utilization and the long-term flight load of the aircraft. AMR and Maintenance Task Scheduling (MTS) activities were integrated on a weekly time horizon problem by Safaei [122]. In this study, routes are created in the first iterative cycle depending on the working hour criteria required for upcoming maintenance tasks, and then MTS is carried out in the second iterative cycle, considering the maintenance alternatives on the routes. If the set of tasks cannot be properly scheduled in the maintenance opportunities, a backtracking strategy is used by repeating the first iterative loop with additional maintenance constraints, referred to as "cuts". Diaz-Ramirez et al. [9] have developed two different methods to solve AMRP and CSP both sequentially and integrated for airlines with a single fleet and a single maintenance and crew base. In the sequential approach, AMRP and CSP were solved by Greedy Heuristic and Column Generation Algorithm, respectively. In the 
integrated approach, the heuristic approach is used to check whether better solutions than those obtained in the sequential approach can be found. Parmentier and Meunier [13], Mohamed et al. [12], and Mohamed et al. [14] are other studies seeking integrated solutions to AMR and Crew Scheduling in problems with a weekly time horizon.

Contrary to the previous belief, according to Başdere and Bilge [21], the weekly time horizon is operationally quite long. Aslamiah et al. [30] support this view with the following statement: The time horizon may be even shorter than a day, as a new schedule will be required for the remainder of the flight leg network due to a disruption during the day. Gürkan et al. [88] presented a solution with a daily time horizon for the problem that deals with flight scheduling, fleet assignment, and aircraft routing together. They used a variable flight time strategy to expand the solution space. In this way, different alternatives have been created, in which whether an aircraft will be used or not and, if so, the flight order for that aircraft changes. Jamili [114] has developed a hybrid algorithm based on Simulated Annealing and Particle Swarm Optimization metaheuristics to solve the integrated aircraft scheduling, routing and fleet assignment model in which the planning period is one day. Liu et al. [115] used a combination of branch-and-price algorithm with column generation approach to solve the daily fleet assignment and aircraft routing problem. Ahmed et al. [15] and Cui et al. [38] are other studies seeking integrated solutions for the problems with a daily time horizon.

Although studies involving a 4-day time horizon are not encountered very often, academicians who are looking for a safe harbour between the daily and weekly planning periods have increased their studies with this feature. Airlines tend to use the 4-day planning horizon in order to ease the requirement of satisfying 1 maintenance visit every 4 days for the aircraft, as mandated by the Federal Aviation Administration [39]. Additionally, the daily horizon assumes that the flight schedule is repeated every day of the week. On the other hand, 4-day or weekly horizons permit different flight schedules for each day of the week. Practically, daily horizon is not viable as airlines permit variations on the flight schedule for each day of the week to cope with the demand fluctuation of different flight legs (e.g. the demand on weekends is higher than other days). In light of this fact, the 4-day horizon is more practical in handling different flight schedules each day [126]. One of these studies,
Eltoukhy et al. [28] used a heuristic model to solve OAMRP in a short computational time. Eltoukhya et al. [121] formulated the coordinated configuration of OAMRP and the Maintenance Staffing Problem as Leader-Follower Stackelberg Game; Eltoukhya et al. [39], unlike the existing OAMRP studies, included operational maintenance constraints such as restrictions on the total cumulative flying time, restrictions on the total number of take-offs, the workforce capacity and the working hours of the maintenance stations in the modelling process. Eltoukhy et al. [37] proposed a new robustness approach called the TurnAround Time Reduction approach to be used in the AMR problem, which includes all maintenance requirements at the same time.

Another important feature in AMRP is the shift period. The shift time of major airlines varies according to the type of maintenance to be performed. Since light maintenance does not take much time, they carry out the service at any time by keeping their technicians at suitable airports or receiving support from other companies. Likewise, these airlines prefer to do their activities when the aircraft is idle or when there is a backup aircraft to complete the heavy maintenance as soon as possible. The exception to this situation is small airlines that operate a limited number of flights with a relatively smaller fleet. These airlines which are called charters prefer to perform the maintenance at night because it is prohibited to land and depart from 23.00/24.00 until 05.00 in some airports. Consequently, depending on the size of the airline, maintenance activities can be performed at any time during the day or overnight.

\subsection{Solution methods}

Stochastic events frequently encountered in the airline industry may affect the status of the aircraft in the fleet, causing infeasibility or increased operational costs in the existing route assignments. So, AMRP is required to be solved very frequently to respond to such changes; which is why developing a fast and responsive solution method is essential [21]. However AMRP is an NP-hard problem [24] for which exact methods are not likely to find effective solutions in a reasonable computational time for large-scale instances. Therefore, in most cases, (meta)heuristic approaches are used to handle this difficulty. Table 2 summarises the solution methods used in some AMRP studies. The general approach in these studies is to use the exact methods that will provide the solution in a short time for small-scale problems prevailing 
in charter companies. However, these methods cannot solve real life problems in a reasonable time. An AMR problem with a daily time horizon should often be solved in 1-1.5 hours. This period will sometimes be shorter due to possible disruptions during the day. Considering today's airlines, which have an incredible number of daily flights and destinations, it cannot be expected from the exact solution methods to yield reasonable results in the specified period. For this reason, studies in which heuristic approaches are used in the solution of such large-scale problems are frequently encountered in the literature. Some of those approaches are Genetic Algorithm in Yang and Yang [18]; Particle Swarm Optimization in Mohamed et al. [12], Sarhani et al. [27], Afia and Sarhani [35]; Variable Neighbourhood Search in Al-Thani et al. [24], Cui et al. [38]; Ant Colony Optimization in Eltoukhy et al. [37] and Simulated Annealing in Afsar et al. [31].

\subsection{Common AMR objectives}

There are many types of objective functions considered in studies in the field of AMRP. While some objectives are directly related to profit and cost, it is seen that some of them have indirect effects. For example, in 2010, 65.000 U.S. airline flights could not take off due to improper MRO, resulting in $\$ 28.2$ million as a penalty cost against 25 U.S. airlines [127]. All airlines aiming to increase their market share in the airline industry must consider multiple factors simultaneously and make a trade-off between them. However, it has been determined that the studies on AMR mostly have a single objective and the existing multi-objective models generally include some of the operational cost items such as crew pairing cost, idle time cost, carbon dioxide (CO2) emission cost, fuel consumption cost, spill cost, daily aircraft usage cost, delay propagation cost, ferry flights cost, maintenance cost, maintenance misalignment cost, maintenance request decline cost, weighted cost of recovery, connection change cost, additive routing cost, etc.

\section{DISCUSSION}

In this article, 117 studies published between 2009 and 2019 are considered to determine the trends in studies on airline operations. As a result of this research, it was determined that the problem of AMR is extremely important in the airline scheduling literature and is studied more than other problems. This finding has led to a more in-depth review of those related to the AMR problem among the 117 articles in question. As a result of examining the AMRP studies, the following findings were obtained.

- The number of short-term maintenance studies is much higher than long-term maintenance, and the number of scheduled maintenance studies is much higher than unscheduled maintenance.

- Although the number of studies with daily and weekly time horizons is close to each other, the number of studies using a 4-day period is quite low compared to these.

- Although maintenance can be performed at any time, it is a common situation to maintain aircraft at night.

- Due to the NP-hard nature of AMRP, heuristic and metaheuristic approaches are generally preferred to solve these problems.

This study revealed that the issues presented below should be taken into account for future studies.

- Besides monetary issues, the academics should deal with many other factors such as delay, flight efficiency and operational risk within their studies. Additionally, academics should pay more attention to the Maintenance Base Location (MBL) Problem which has a direct impact on AMRP results.

- The transportation sector is one of the sources of many problems such as global warming, environmental degradation, and greenhouse gas emission. Air transportation, the second most preferred type of transportation, has a great effect on this problem. Although this situation requires increasing scientific contributions to reduce the negative environmental impact, this goal was studied only in Gürkan et al. [88].

- Special solution procedures integrating AMRP with Artificial Intelligence (AI) have to be developed to obtain better results in terms of solution time and quality.

- Solution approaches including algorithms to repeat the problem-specific parameter fitting process in each new AMRP problem are required to be designed.

\section{CONCLUSIONS}

The airline industry has shown significant growth in the last decade. This inevitable progress makes the airline industry challenging and forces airline companies to advance in distinct airline operations. 
However, although such operations have been studied for several years, the literature review on airline scheduling is still missing for the last decade. This study aims to fill this gap by reviewing the airline operations related papers published between 2009 and 2019, and focus on the ones especially dealing with the AMR area which seems a promising branch.

Hence, 117 studies published between 2009 and 2019 are first considered to determine the trends in studies on airline operations, and later the papers related to the AMRP are studied in more depth in terms of mostly considered maintenance types, applied time horizon and ship period, and finally the used solution methods and objectives. At the end of the review, not only some general ideas are proposed but also future remarks are given in order to enable progress of future studies.

\section{Dr. TOLGA TEMUÇIN ${ }^{1}$}

E-mail: tolga.temucin@gmail.com

Prof. Dr. GÜLFEM TUZKAYA ${ }^{1}$

E-mail: gulfem.tuzkaya@marmara.edu.tr

Prof. Dr. ÖZALP VAYVAY ${ }^{1}$

E-mail: ozalp@marmara.edu.tr

${ }^{1}$ Marmara Üniversitesi Göztepe Kampüsü

Endüstri Mühendisliği Departmanı

34722 Kadıköy - İstanbul, Turkiye

\section{UÇAK BAKIM ROTALAMA PROBLEMI: BIR LITERATÜR ARAŞTIRMASI}

\section{$\ddot{O Z Z T T}$}

Küresel hava trafiği yolcu talebindeki ylllık ortalama büyüme ve küresel hava taşımacıllğg filosundaki büyüme oranı gibi bazı göstergelere göre, havayolu sektörü son on yılda önemli bir büyüme göstermiştir. Bu kaçınılmaz ilerleme, havayolu endüstrisini zorlu hale getirmekte ve havayolu șirketlerini tüketicinin markaya olan bağlllığını artıran bir dizi çözüm üretmeye zorlamaktadır. Havayolu operasyonlarında karşılaşılan yüksek maliyetleri azaltmak, planlanan kalkış saatlerinde gecikmeleri önlemek, hizmet kalitesini iyileştirmek veya çevresel etkileri azaltmak amacını güden bu çözümler ihtiyaca göre çeşitlendirilebilir. Bu konuda geçmişte yapılan araştırmalar özellikle son on yulda havayolu çizelgelemesine iliş̧kin zengin literatürü kapsamamaktadır. Bu çalışma, 2009-2019 yllları arasinda yaymlanan havayolu operasyonlart ile ilgili makaleleri gözden geçirerek bu boşluğu doldurmayı ve özellikle gelecek vaat eden bir dal gibi görünen uçak bakım rotalama alanında olanlara odaklanmayı amaçlamaktadir.

\section{ANAHTAR KELIMELER}

havayolu operasyonlarl; havayolu çizelgeleme; uçak bakım rotalama.

\section{REFERENCES}

[1] Air Transport Action Group. Aviation: Benefits Beyond Borders. 2018. Available from: https://aviationbenefits. org/media/166712/abbb18_global-summary_web.pdf [Accessed 13th June 2020].

[2] Mazareanu E. Global Air Traffic - Annual Growth of Passenger Demand 2006-2021. 2020. Available from: https:// www.statista.com/statistics/193533/growth-of-globalair-traffic-passenger-demand/ [Accessed 21st June 2020].

[3] Demir R. Aviation Industry: MRO Trends Summary Q12014. 2014. Available from: https://www.slideshare.net/ reyyandemir/aviation-industry-and-mro-sector-trends [Accessed 21st June 2020].

[4] Battles B. Maintenance Costs: Significant but Tricky. 2003. Available from: https://www.aviationpros.com/ aircraft/maintenance-providers/mro/article/10387195/ aircraft-maintenance-costs-significant-but-tricky. [Accessed 4th April 2019].

[5] The International Air Transport Association. IATA Annual Review 2017. 2017. Available from: http://www.iata. org/publications/Documents/iata-annual-review-2017. pdf [Accessed 17th March 2018].

[6] Chen D, Wang X, Zhao J. Aircraft maintenance decision system based on real-time condition monitoring. Procedia Engineering. 2012;29: 765-769.

[7] Zhou G, Zhang H. The design and implementation of aircraft maintenance on-site control system. Physics Procedia. 2012;33: 528-534.

[8] Colbacchini S, Gahafer A, McEvoy L, Park B. Simulation of the support fleet maintenance of modern stealth fighter aircraft. Proceedings of the IEEE Systems and Information Engineering Design Conference, SIEDS 2016, 29 April 2016, Virginia, USA; 2016.

[9] Díaz-Ramírez J, Huertas JI, Trigos F. Aircraft maintenance, routing, and crew scheduling planning for airlines with a single fleet and a single maintenance and crew base. Computers \& Industrial Engineering. 2014;75: 68-78.

[10] Weide O, Ryan D, Ehrgott M. An iterative approach to robust and integrated aircraft routing and crew scheduling. Computers \& Operations Research. 2010;37(5): 833-844.

[11] Dunbar M, Froyland G, Wu C. An integrated scenario-based approach for robust aircraft routing, crew pairing and re-timing. Computers \& Operations Research. 2014;45: 68-86.

[12] Mohamed NF, et al. A heuristic and exact method: Integrated aircraft routing and crew pairing problem. Modern Applied Science. 2016;10(4): 128-136.

[13] Parmentier A, Meunier F. Aircraft Routing and Crew Pairing: Updated Algorithms at Air France. $a r X$ iv:1706.06901. 2017.

[14] Mohamed NF, Zainuddin ZM, Salhi S, Mohamed NA. The integrated aircraft routing and crew pairing problem: ILP based formulations. Jurnal Teknologi. 2016;78(6-5): 79-85. 
[15] Ahmed MB, Mansour FZ, Haouari M. Robust integrated maintenance aircraft routing and crew pairing. Journal of Air Transport Management. 2018;73(C): 15-31.

[16] Lacasse-Guay E, Desaulniers G, Soumis F. Aircraft routing under different business processes. Journal of Air Transport Management. 2010;16(5): 258-263.

[17] Papakostas N, et al. An approach to operational aircraft maintenance planning. Decision Support Systems. 2010;48(4): 604-612.

[18] Yang Z, Yang G. Optimization of aircraft maintenance plan based on genetic algorithm. Physics Procedia. 2012;33: 580-586

[19] Maher SJ, Desaulniers G, Soumis F. Recoverable robust single day aircraft maintenance routing problem. Computers \& Operations Research. 2014;51: 130-145.

[20] Liang Z, et al. Robust weekly aircraft maintenance routing problem and the extension to the tail assignment problem. Transportation Research Part B: Methodological. 2015;78: 238-259.

[21] Başdere M, Bilge Ü. Operational aircraft maintenance routing problem with remaining time consideration. $E u$ ropean Journal of Operational Research. 2014;235(1): 315-328.

[22] Irvine EA, Shine KP, Stringer MA. What are the implications of climate change for trans-atlantic aircraft routing and flight time? Transportation Research Part D: Transport and Environment. 2016;47: 44-53.

[23] Gopalan R. The aircraft maintenance base location problem. European Journal of Operational Research. 2014;236(2): 634-642.

[24] Al-Thani NA, Ahmed MB, Haouari M. A model and optimization-based heuristic for the operational aircraft maintenance routing problem. Transportation Research Part C. 2016;72: 29-44.

[25] Safaei N, Jardine AKS. Aircraft routing with generalized maintenance constraints. Omega. 2018;80: 111-122.

[26] Qin Y, Chan FTS, Chung SH, Qu T. Development of MILP model for integrated aircraft maintenance scheduling and multi-period parking layout planning problems. Proceedings of the $4^{\text {th }}$ International Conference on Industrial Engineering and Applications, ICIEA 2017, 2729 April 2017, Nagoya, Japan; 2017. p. 197-203.

[27] Sarhani M, Ezzinbi O, El Afia A, Benadada Y. Particle swarm optimization with a mutation operator for solving the preventive aircraft maintenance routing problem. Proceedings of the $3^{\text {rd }}$ International Conference on Logistics Operations Management, GOL 2016, 23-25 May 2016, Fez, Morocco; 2016. p. 1-6.

[28] Eltoukhy AEE, Chan FTS, Chung SH, Qu T. Optimization model and solution method for operational aircraft maintenance routing problem. Proceedings of the World Congress on Engineering, WCE 2017, 5-7 July 2017, London, U.K.

[29] Orhan I, Kapanoğlu M, Karakoç TH. Concurrent aircraft routing and maintenance scheduling. Journal of Aeronautics and Space Technologies. 2011;5(1): 73-79.

[30] Aslamiah S, et al. Integer programming model for operational aircraft maintenance routing problem with side constraints. Proceedings of the $6^{\text {th }}$ IMT-GT Conference on Mathematics, Statistics and Its Applications, ICMSA 2010, Kuala Lumpur, Malaysia.
[31] Afsar HM, Espinouse M-L, Penz B. Building flight planning for an airline company under maintenance constraints. Journal of Quality in Maintenance Engineering. 2009;15(4): 430-443.

[32] Kim SJ, Lim GJ, Cho J. Drone flight scheduling under uncertainty on battery duration and air temperature. Computers \& Industrial Engineering. 2018;117: 291-302.

[33] Bulbul KG, Kasımbeylı R. An augmented lagrangian relaxation based subgradient approach to aircraft maintenance routing problem. Proceedings of the $6^{\text {th }}$ International Conference on Control and Optimization with Industrial Applications, COIA 2018, 11-13 July 2018, Baku, Azerbaijan.

[34] Zhong M, Chan FTS, Chung SH. Operational aircraft routing problem: Some insights in the capacitated maintenance resources. Proceedings of the IEEE International Conference on Industrial Engineering and Engineering Management, IEEM 2018, 16-19 December 2018, Bangkok, Thailand; 2018. p. 401-405.

[35] Afia AE, Sarhani M. Optimization of a predictive aircraft maintenance routing model using mutated constrained particle swarm optimization. In: Lincoln CW. (eds.) Contemporary approaches and strategies for applied logistics. Pennsylvania, USA: IGI Global; 2018. p. 365-381.

[36] Zhang X. Optimization of Flight Scheduling Problem by MATLAB. 2018. Available from: https://openscholarship.wustl.edu/cgi/viewcontent.cgi?article $=1000 \&$ context $=$ mems5001 [Accessed 17th March 2021].

[37] Eltoukhy AEE, et al. Robust aircraft maintenance routing problem using a turn-around time reduction approach. IEEE Transactions on Systems, Man, and Cybernetics: Systems. 2019;50(12): 4919-4932.

[38] Cui R, Dong X, Lin Y. Models for aircraft maintenance routing problem with consideration of remaining time and robustness. Computers \& Industrial Engineering. 2019;137: 106045 .

[39] Eltoukhya AEE, Chana FTS, Chunga SH, Niub B. A model with a solution algorithm for the operational aircraft maintenance routing problem. Computers \& Industrial Engineering. 2018;120: 346-359.

[40] Vos HM, Santos BF, Omondi T. Aircraft schedule recovery problem - A dynamic modeling framework for daily operations. Transportation Research Procedia. 2015;10: 931-940.

[41] Zhang D, Lau HH, Yu C. A two stage heuristic algorithm for the integrated aircraft and crew schedule recovery problems. Computers \& Industrial Engineering. 2015;87: 436-453.

[42] Dožić S, Kalić M, Babić O. Heuristic approach to the airline schedule disturbances problem: Single fleet case. Procedia - Social and Behavioral Sciences. 2012;54: 1232-1241.

[43] Liu T, Chen C, Chou J. Optimization of short-haul aircraft schedule recovery problems using a hybrid multiobjective genetic algorithm. Expert Systems with Applications. 2010;37(3): 2307-2315.

[44] $\mathrm{Hu} \mathrm{Y}$, et al. Optimization of multi-fleet aircraft routing considering passenger transiting under airline disruption. Computers \& Industrial Engineering. 2015;80: 132-144.

[45] Jufri SA, et al. Arrival time flight scheduling in Kuala Lumpur international airport (KLIA). Journal of 
Transport System Engineering. 2018;5(1): 31-36.

[46] Lin H, Wang Z. Flight scheduling for airport closure based on sequential decision. Proceedings of the $4^{\text {th }}$ International Conference on Information Management, ICIM 2018, 25-27 May 2018, Oxford, UK; 2018. p. 241-245.

[47] Akartunalı K, et al. Airline planning benchmark problems - Part I: Characterising networks and demand using limited data. Computers \& Operations Research. 2013;40(3): 775-792.

[48] Akartunalı K, et al. Airline planning benchmark problems - Part II: Passenger groups, utility and demand allocation. Computers \& Operations Research. 2013;40(3): 793-804.

[49] Burke EK, et al. A multi-objective approach for robust airline scheduling. Computers \& Operations Research. 2010;37(5): 822-832.

[50] Chen C, Yan S, Chen M. Applying lagrangian relaxation-based algorithms for airline coordinated flight scheduling problems. Computers \& Industrial Engineering. 2010;59(3): 398-410.

[51] Sun JY. Clustered airline flight scheduling: Evidence from airline deregulation in Korea. Journal of Air Transport Management. 2015;42: 85-94.

[52] Jiang H, Barnhart C. Robust airline schedule design in a dynamic scheduling environment. Computers \& Operations Research. 2013;40(3): 831-840.

[53] Abdelghany A, Abdelghany K, Azadian F. Airline flight schedule planning under competition. Computers and Operations Research. 2017;87: 20-39.

[54] Sandamali GGN, Su R, Zhang Y, Li Q. Flight routing and scheduling with departure uncertainties in air traffic flow management. Proceedings of the $13^{\text {th }}$ IEEE International Conference on Control \& Automation, ICCA 2017, 03-06 July 2017, Ohrid, Macedonia; 2017. p. 301-306.

[55] Zhao S, Shao W, Zhu H. The intelligent decision of flights adjusting rule-based flight scheduling optimisation. Proceedings of the International Conference on Web Search and Data Mining, WSDM 2019, 11-15 February 2019, Melbourne, Australia.

[56] Peng Y, Tang Q, Han Y. Research on the optimisation of flight landing scheduling with multi-runway. International Journal of Computing Science and Mathematics. 2018;9(6): 602-611.

[57] Chen X, et al. Uncertainty-aware flight scheduling for airport throughput and flight delay optimization. IEEE Transactions on Aerospace and Electronic Systems. 2019;56(2): 853-862.

[58] Wang Z, Zhang X. An approach of flight scheduling optimization meet the time conformance monitoring. Proceedings of the $13^{\text {th }}$ World Congress on Intelligent Control and Automation, WCICA 2018, 4-8 July 2018, Changsha, China; 2018. p. 1647-1651.

[59] Ahmadian N, Lim GJ, Torabbeigi M, Kim SJ. Collision-free multi-UAV flight scheduling for power network damage assessment. Proceedings of the International Conference on Unmanned Aircraft Systems, ICUAS 2019, 11-14 June 2019, Atlanta, USA; 2019. p. 794-798.

[60] Azadeh A, et al. A hybrid meta-heuristic algorithm for optimization of crew scheduling. Applied Soft Computing. 2013;13(1): 158-164.

[61] Deng G, Lin W. Ant colony optimization-based algorithm for airline crew scheduling problem. Expert Systems with Applications. 2011;38(5): 5787-5793.

[62] Ionescu L, Kliewer N. Increasing flexibility of airline crew schedules. Procedia - Social and Behavioral Sciences. 2011;20: 1019-1028.

[63] Dück V, Ionescu L, Kliewer N, Suhl L. Increasing stability of crew and aircraft schedules. Transportation Research Part C: Emerging Technologies. 2012;20(1): 47-61.

[64] Saddoune M, Desaulniers G, Elhallaoui I, Soumis F. Integrated airline crew scheduling: A bi-dynamic constraint aggregation method using neighborhoods. European Journal of Operational Research. 2011;212(3): 445-454.

[65] Suraweera P, Webb GI, Evans I, Wallace M. Learning crew scheduling constraints from historical schedules. Transportation Research Part C: Emerging Technologies. 2013;26: 214-232.

[66] Bayliss C, De Maere G, Atkin JAD, Paelinck M. A simulation scenario based mixed integer programming approach to airline reserve crew scheduling under uncertainty. Annals of Operations Research. 2017;252(2): 335-363.

[67] Kasirzadeh A, Saddoune M, Soumis F. Airline crew scheduling: Models, algorithms, and data sets. EURO Journal on Transportation and Logistics. 2017;6(2): 111-137.

[68] Lijima Y, Nishi T. Column generation heuristics to airline crew scheduling problem for fair working time. Proceedings of the IEEE International Conference on Systems, Man, and Cybernetics, SMC2016, 9-12 October 2016, Budapest, Hungary.

[69] Arayikanon K, Chutima P. Solving cockpit crew scheduling problem of a low-cost airline using metaheuristics. AIP Conference Proceedings. 2018;2044: 020002.

[70] Ozdemir Y, Basligil H, Sarsenov B. A large scale integer linear programming to the daily fleet assignment problem: A case study in Turkey. Procedia - Social and Behavioral Sciences. 2012;62: 849-853.

[71] Pilla VL, et al. A multivariate adaptive regression splines cutting plane approach for solving a two-stage stochastic programming fleet assignment model. European Journal of Operational Research. 2012;216(1): 162-171.

[72] Kang Z, Ying Y, Weijie W. A dynamic flight stringbased ant colony algorithm for fleet assignment. Proceedings of the IEEE Information Technology, Networking, Electronic and Automation Control Conference, ITNEC 2016, 20 22 May 2016, Chongqing, China; 2016. p. 302-306.

[73] Yang Z, et al. An improved ant colony algorithm for mapreduce-based fleet assignment problem. Proceedings of the $2^{\text {nd }}$ Advanced Information Technology, Electronic and Automation Control Conference, IAEAC 2017, 25-26 March 2017, Chongqing, China; 2017. p. 104-108.

[74] Ma Q, Song H, Zhu W. Low-carbon airline fleet assignment: A compromise approach. Journal of Air Transport Management. 2018;68: 86-102.

[75] Raudasoja L. How to include ancillaries in fleet assignment optimization: Case Finnair. Bachelor thesis. Aalto University; 2018.

[76] Boudia M, Delahaye T, Gabteni S, Acuna-Agost R. Novel approach to deal with demand volatility on fleet assignment models. Journal of the Operational Research 
Society. 2017;69(6): 895-904.

[77] Liu M, Liang B, Zheng F, Chu F. Stochastic airline fleet assignment with risk aversion. Transactions on Intelligent Transportation Systems. 2019;20(8): 3081-3090.

[78] Dozic S, Jelovic A, Kalic M, Cangalovic M. Variable neighborhood search to solve an airline fleet sizing and fleet assignment problem. Transportation Research Procedia. 2019;37: 258-265.

[79] Okafor EG, et al. Study of fleet assignment problem using a hybrid technique based on Monte Carlo simulation and genetic algorithm. Nigerian Journal of Technology. 2019;38(3): 756-762.

[80] Anzoom R, Hasin MAA. Optimal fleet assignment using ant colony algorithm. Proceedings of the International Conference on Production and Operations Management Society, POMS 2018, 14-16 December 2018, Peradeniya, Sri Lanka; 2018. p. 1-6.

[81] Silva M, Poss M. Distributionally Robust airline fleet assignment problem. Proceedings of the International Network Optimization Conference, INOC 2019, 12-14 June 2019, Avignon, France.

[82] Su AJ, Yang WD, Zhang C, Kong MX. 2019. Robust Modeling for Fleet Assignment Problem Based on GASVR Forecast. Journal of Physics: Conf. Series 1187. DOI: 10.1088/1742-6596/1187/4/042062

[83] Dahel N-E. A fleet assignment model for optimizing military airlift. Proceedings of the $47^{\text {th }}$ Annual Meeting of Western Decision Sciences Institute, WDSI 2018, 3-6 April 2018, USA.

[84] Bruecker PD, Bergh JV, Beliën J, Demeulemeester E. A model enhancement heuristic for building robust aircraft maintenance personnel rosters with stochastic constraints. European Journal of Operational Research. 2015;246(2): 661-673.

[85] Qiang F, Songjie L, Bo S. A multi-agent based intelligent configuration method for aircraft fleet maintenance personnel. Chinese Journal of Aeronautics. 2014;27(2): 280-290.

[86] Mackenzie A, Miller J, Hill RR, Chambal SP. Application of agent based modelling to aircraft maintenance manning and sortie generation. Simulation Modelling Practice and Theory. 2012;20(1): 89-98.

[87] Datta PP, Srivastava A, Roy R. A simulation study on maintainer resource utilization of a fast jet aircraft maintenance line under availability contract. Computers in Industry. 2013;64(5): 543-555.

[88] Gürkan H, Gürel S, Aktürk MS. An integrated approach for airline scheduling, aircraft fleeting and routing with cruise speed control. Transportation Research Part C: Emerging Technologies. 2016;68: 38-57.

[89] Dong Z, Chuhang Y, Lau HH. An integrated flight scheduling and fleet assignment method based on a discrete choice model. Computers \& Industrial Engineering. 2016;98: 195-210.

[90] Cadarso L, Marín Á. Robust passenger oriented timetable and fleet assignment integration in airline planning. Journal of Air Transport Management. 2013;26: 44-49.

[91] Pita JP, Adler N, Antunes AP. Socially oriented flight scheduling and fleet assignment model with an application to Norway. Transportation Research Part B: Methodological. 2014;61: 17-32.
[92] Cadarsoa L, Marín Á. Integrated robust airline schedule development. Procedia - Social and Behavioral Sciences. 2011;20: 1041-1050.

[93] Kenan N, Jabali A, Diabat A. An integrated flight scheduling and fleet assignment problem under uncertainty. Computers \& Operations Research. 2018;100: 333-342.

[94] Mezentsev Y, Estraykh I. An optimal fleet assignment and flight scheduling problem for an airline company. Proceedings of the Russian Higher School Academy of Sciences; 2018. p. 74-90.

[95] Tsagkas V, Nathanael D, Marmaras N. A pragmatic mapping of factors behind deviating acts in aircraft maintenance. Reliability Engineering \& System Safety. 2014;130: 106-114.

[96] Gerede E. A qualitative study on the exploration of challenges to the implementation of the safety management system in aircraft maintenance organizations in Turkey. Journal of Air Transport Management. 2015;47: 230-240.

[97] Gerede E. A study of challenges to the success of the safety management system in aircraft maintenance organizations in Turkey. Safety Science. 2015;73: 106-116.

[98] Chang Y, Wang Y. Significant human risk factors in aircraft maintenance technicians. Safety Science. 2010;48(1): 54-62.

[99] Atak A, Kingma S. Safety culture in an aircraft maintenance organisation: A view from the inside. Safety Science. 2011;49(2): 268-278.

[100] Quinlan M, Hampson I, Gregson S. Outsourcing and offshoring aircraft maintenance in the US: Implications for safety. Safety Science. 2013;57: 283-292.

[101] Passenier D, Mols C, Bim J, Sharpanskykh A. Modeling safety culture as a socially emergent phenomenon: A case study in aircraft maintenance. Computational and Mathematical Organization Theory. 2016;22(4): 487-520.

[102] Murça MC, Müller C. Control-based optimization approach for aircraft scheduling in a terminal area with alternative arrival routes. Transportation Research Part E: Logistics and Transportation Review. 2015;73: 96-113.

[103] Samà M, D'Ariano A, D'Ariano P, Pacciarelli D. Optimal aircraft scheduling and routing at a terminal control area during disturbances. Transportation Research Part C: Emerging Technologies. 2014;47: 61-85.

[104] Samà M, D'Ariano A, Pacciarelli D. Rolling horizon approach for aircraft scheduling in the terminal control area of busy airports. Transportation Research Part E: Logistics and Transportation Review. 2013;60: 140-155.

[105] Shanmugam A, Robert TP. Ranking of aircraft maintenance organization based on human factor performance. Computers \& Industrial Engineering. 2015;88: 410-416.

[106] Yadav DK. Licensing and recognition of the aircraft maintenance engineers - A comparative study. Journal of Air Transport Management. 2010;16(5): 272-278.

[107] Kasava NK, Yusof NM, Khademi A, Saman MZ. Sustainable domain value stream mapping (SdVSM) framework application in aircraft maintenance: A case study. Procedia CIRP. 2015;26: 418-423.

[108] Mofokeng TJ, Marnewick A. Factors contributing to delays regarding aircraft during A-check maintenance. Proceedings of the IEEE Technology \& Engineering Management Conference, TEMSCON 2017, 08-10 June 2017, Santa Clara, USA. 2017. p. 185-190. 
[109] Noweir MH, Zytoon MA. Occupational exposure to noise and hearing thresholds among civilian aircraft maintenance workers. International Journal of Industrial Ergonomics. 2013;43(6): 495-502.

[110] Irwin E, Streilein K. Use of field-based motion capture to augment observational data in ergonomic assessment of aircraft maintenance. Procedia Manufacturing. 2015;3: 4501-4508.

[111] Babic O, Kalic M, Babic D, Dozic S. The airline schedule optimization model: Validation and sensitivity analysis. Procedia - Social and Behavioral Sciences. 2011;20: 1029-1040.

[112] Sandamali GGN, Su R, Zhang Y. Flight routing and scheduling under departure and en route speed uncertainty. IEEE Transactions on Intelligent Transportation Systems. 2019;21(5): 1915-1928.

[113] Lindner M, Rosenow J, Förster S, Fricke H. Potential of integrated flight scheduling and rotation planning considering aerodynamic-, engine- and mass-related aircraft deterioration. CEAS Aeronautical Journal. 2019;10: 755770.

[114] Jamili A. A robust mathematical model and heuristic algorithms for integrated aircraft routing and scheduling with consideration of fleet assignment problem. Journal of Air Transport Management. 2017;58: 21-30.

[115] Liu W-M, Zhu X-H, Qi Y-L. Integrated fleet assignment and aircraft routing based on delay propagation. Sadhana. 2016;41(7): 713-719.

[116] Özener OÖ, et al. Solving a large-scale integrated fleet assignment and crew pairing problem. Annals of Operations Research. 2017;253(1): 477-500.

[117] Komijan AR, Tavakkoli-Moghaddam R, Dalil SA. A mathematical model for an integrated airline fleet assignment and crew scheduling problem solved by vibration damping optimization. Scientica Iranica. 2019.

[118] Abdelrahman EEE. Optimizing aircraft routing of airline and maintenance staffing of maintenance providers using game theoretic model. PhD thesis. The Hong Kong Polytechnic University; 2018.
[119] Chan FTS, Eltoukhy AEE. Investigating the interrelationship between stochastic aircraft routing of airlines and maintenance staffing of maintenance providers. Proceedings of the $5^{\text {th }}$ International Conference on Industrial Engineering and Applications, ICIEA 2018, 26-28 April 2018, Singapore, Singapore. 2018. p. 254-261.

[120] Eltoukhya AEE, Wangb ZX, Chana FTS, Fuc X. Data analytics in managing aircraft routing and maintenance staffing with price competition by a stackelberg-nash game model. Transportation Research Part E. 2019;122(C): 143-168.

[121] Eltoukhya AEE, Wangb ZX, Chana FTS, Chunga SH. Joint optimization using a leader-follower stackelberg game for coordinated configuration of stochastic operational aircraft maintenance routing and maintenance staffing. Computers \& Industrial Engineering. 2018;125: 46-68.

[122] Safaei N. Combined Aircraft Maintenance Routing and Maintenance Task Scheduling. 2016. Available from: https://patentimages.storage.googleapis.com/1f/d8/ 84/375070a1f0e7ea/WO2016157099A1.pdf [Accessed 25th August 2020].

[123] Smith BC, Leimkuhler JF, Darrow RM. Yield management at American Airlines. Interfaces. 1992;22(1): 8-32.

[124] Subramanian R, et al. Coldstart: Fleet assignment at Delta Air Lines. Interfaces. 1994;24(1): 104-120.

[125] Van den Bergh J, de Bruecker P, Beliën J, Peeters J. Aircraft maintenance operations: State of art. Faculty of Economics and Business, HUBrussel. Report number: 2013/09, 2013.

[126] Eltoukhy AEE, Chan FTS, Chung SH. Airline schedule planning: A review and future directions. Industrial Management \& Data Systems. 2017;117(6): 1201-1243.

[127] Stoller G. USA Today: Planes with Maintenance Problems Flown Anyway. 2010. Available from: https://forums. jetcareers.com/threads/usa-today-planes-with-maintenance-problems-flown-anyway.102981/ [Accessed 17th March 2018]. 